\title{
Morphology of Flesh Fly Peckia (Peckia) chrysostoma (Diptera: Sarcophagidae) Revealed by Scanning Electron Microscopy
}

\author{
Carriço C ${ }^{1}$, Caetano RL ${ }^{2,3 *}$, Barbán Alvarez LDR ${ }^{4}$ \\ and Pinto $\mathrm{ZT}^{\mathbf{1}}$ \\ ${ }^{1}$ Instituto Oswaldo Cruz/ Fundação Oswaldo Cruz (IOC/ \\ FIOCRUZ), Laboratório de Educação em Ambiente e \\ Saúde, Brazil \\ ${ }^{2}$ Instituto Oswaldo Cruz/ Fundação Oswaldo Cruz (IOC/ \\ FIOCRUZ), Laboratório de Referência Nacional em \\ Vetores das Riquetsioses (LIRN), Brazil \\ ${ }^{3}$ Universidade Estácio de Sá (UNESA), Campus \\ Petrópolis, Brazil \\ ${ }^{4}$ Instituto de Ecologia y Sistemática, Cuba \\ *Corresponding author: Rebecca Leal Caetano, \\ Instituto Oswaldo Cruz/ Fundação Oswaldo Cruz (IOC/ \\ FIOCRUZ), Laboratório de Referência Nacional em \\ Vetores das Riquetsioses (LIRN), Avenida Brasil, 4365. \\ CEP 21040-900. Rio de J aneiro, RJ , Brazil
}

Received: April 26, 2017; Accepted: May 30, 2017;

Published: June 12, 2017

\section{Introduction}

The Family Sarcophagidae along with the families Calliphoridae, Muscidae, Fanniidae and, Stratiomyidae are of great importance to public health and Forensic Entomology [1-3]. Most Sarcophagidae species is ovoviviparous, eliminating first in star larvae that immediately begin their feeding on the carcass, giving the Sarcophagidae one pioneering colonization of corpses, which highlights its forensic importance [4]. The species from this family also can be of medical and veterinary importance, since they are capable of producing myiasis in humans and animals, besides of carrying pathogens [5-7].

Adults from Sarcophagidae species are difficult to identify and can only be successfully identified after careful analysis of the genitalia region, mainly from males [8,9]. Their external morphology is either too uniform or vary too much, being generally useless for identification purposes [9].

According to [3] Sarcophagidae family presents some genus of forensic importance to South America as Blaesoxipha Loew, 1861, Engelimyia Lopes, 1975, Helicobia Coquillett, 1895, Microcerella Macquart, 1851, Oxysarcodexia Townsend, 1917, Peckia RobineauDesvoidy, 1830, Ravinia Robineau-Desvoidy, 1863, Sarcophaga Meigen, 1826, Titanogrypa Townsend, 1917 and Tricharaea Thomson, 1869.

Following [10] the Sarcophagidae specimens of forensic importance in Brazil are: Peckia (Pattonella) ingens Walker, 1849, Peckia (Pattonella) intermutans (Walker, 1861), Peckia (Pattonella) pallidipilosa (Curran \& Walley, 1934), Peckia (Pattonella) smarti (Lopes 1941), Peckia (Peckia) Chrysostoma (Wiedemann, 1830),
Sarcophaga (Bercaea) africa Wiedemann, 1824, Sarcophaga (Liopygia) ruficornis Fabricius, 1794 and Squamatoides trivittatus Curran, 1927.

Morphological studies, using scanning electron microscopy (SEM) to clarify some structures from adults flies of public health and forensic importance were performed by $[8,11-13,7]$ to help increase the anatomical database on flies. Nevertheless, there are few studies about ultrastructure of terminal ends and sensorial organs of Sarcophagidae species. An ultrastructure analysis of the terminal end and sensilla on the antennae by SEM of Peckia (Peckia) chrysostoma had not yet been performed. The purpose of this study was to examine in details by SEM theses ultrastructures on this specie of public health and forensic importance to help increase the anatomical database on flies.

\section{Materials and Methods}

Sarcophagidae species were obtained from traps made with plastic bottles [14], with carrion of Sardinella brasiliensis (Steindachner 1879) and the collections were performed daily, during october of 2016, in a Atlantic rainforest fragment at Instituto Samambaia de Ciências Ambientais e Ecoturismo (ISCA) - Petrópolis, Rio de Janeiro, Brazil $\left(22^{\circ} 46^{\prime} 90^{\prime \prime} \mathrm{S}\right.$ and $\left.43^{\circ} 14^{\prime} 82^{\prime \prime} \mathrm{W}\right)$.

Males from Peckia (Peckia) chrysostoma were sorted out and their terminalia were distended allowing proper identification following [3]. The terminal ends and heads were dissected from 10 male under dissecting microscope. These structures were then processed for SEM examination by transferring to $2.5 \%$ of glutaraldehyde mixture in phosphate buffered saline (PBS) for 24h. Beyond, specimens were rinsed twice with PBS at 10 minutes intervals and post fixed with $1 \%$ of osmium tetroxide at room temperature for 3 days. The flesh flies 


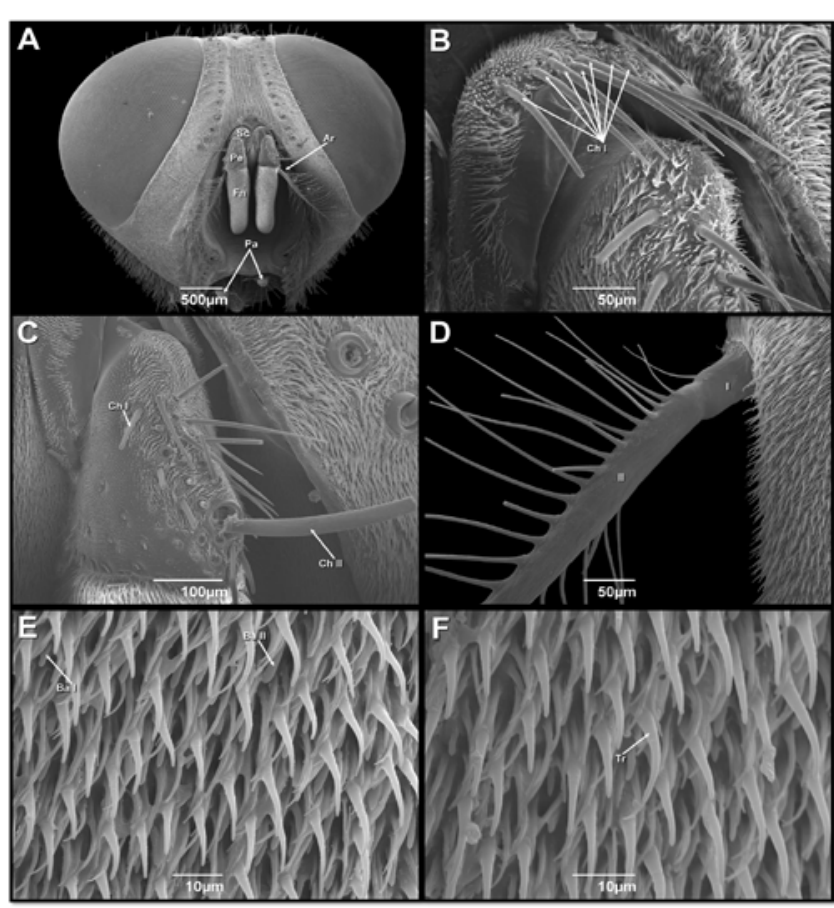

Figure 1: Scanning electron micrographs of head of male of Peckia (Peckia) Chrysostoma. (A) Frontal view of head showing the antennae (with a proximal scape - Sc; an intermediate pedicel - Pe, and terminal flagellum with: Arista Ar and Funiculus - Fn) and palps. (B) Scape - the arrows indicate the bases of chaetic sensilla (Chl). (C) Pedicel - with two types of chaetic sensilla (Chl and Ch II). (D) Proximal side of arista. (E) Surface of the funiculus - Basiconic sensilla - (Ba I and Ba II). (F) Surface of the funiculus - Trichoidea sensilla (Tr).

were then rinsed twice with $\mathrm{PBS}$ and dehydrated in an increasing graded series of alcohol (30, 50, 70, 80 and 90\%) for $12 \mathrm{~h}$ during each step. After that, flies were placed in absolute alcohol, followed by treatment in acetone. The next step, the specimens were subjected to critical point drying and placed on metallic supports, coated with a thin gold layer $(20-30 \mathrm{~nm})$ and examined under JEOL 6390LV scanning electron microscope (SEM) (Akishima, Tokyo, Japan). The terminologies for external and genital morphologies of adults flies used in this study followed [15-17] for some phallic structures characteristic of Sarcophagidae. The classification of sensilla followed by $[11,12,18]$.

\section{Results}

SEM observations of the head of male Peckia (Peckia) chrysostoma revealed a pair of antennae typically of cyclorrhaphan Diptera, frontally situated, between the large compounds eyes (Figure 1A). Antenna morphology consisting in three segments: the first called scape $(\mathrm{Sc})$, the second pedicel $(\mathrm{Pe})$ and a third flagellum composed of a seta called arista (Ar) located laterally and an enlarged basal funiculus (Fn) (Figure 1A). All antennal segments in this species have sensilla.

The scape is densely covered by microtrichia, and only one type of sensilla was observed: seven chaetic sensilla (Ch I) of similar length which were noticed arranged in a single row, this sensilla is longitudinally grooved and has a finely tapered, acute tip (Figure 1B). The pedicel surface is covered by similar microtrichia to those found

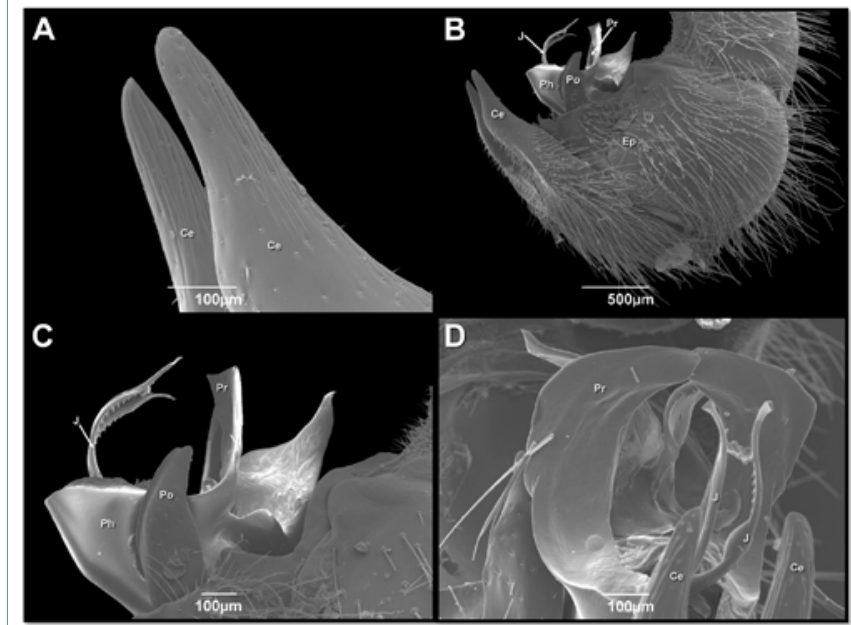

Figure 2: Scanning electron micrographs of male genitalia of Peckia (Peckia) Chrysostoma (A-D). Cerci (Ce); Epandrium (Ep); Juxta (J); Phallus (Ph); Postgonite (Po); Pregonites (Pr).

on the scape (Figure 1C) and shows two types of chaetic sensilla (Ch I and Ch II). The first type (Ch I) is represented by a group of 15 bristles, similar to those found on the scape. The second type (Ch II) is represented by a singular bristle in the distal outer edge region (Figure 1C). The distal flagellum is the longest antenna segment and numerous sensilla are found on then. Arising closed to the base of the funiculus on its dorsolateral surface is the plumose arista, which is composed of two segments (Figure 1D). The enlarged basal Fn are densely covered by microtrichia similar to those found on the scape and pedicel. Interspersed among the microtrichia are two types of sensilla: trichoidea and two type of basiconic (Ba I and Ba II) (Figure $1 \mathrm{E}, \mathrm{F})$.

SEM observations of male terminalia showing in Peckia Chrysostoma the presence of sensilla. The prominent appendages of cerci were wide and curved at the apical region (Figure 2A). The postgonite (Po) were short and cuverd upward apically and situated between the cerci $(\mathrm{Ce})$ and the phallus (Ph) (Figure 2B,C). The phallus located were connected to the pregonites (Pr) and epandrium (Ep) (Figure 2B-C). The terminal end of the juxta (J) was slightly expanded with a laterally serrated structure (Figure 2D).

\section{Discussion}

The present study is the first describing the morphology of the different parts of the antennae and male genitalia by SEM of flesh fly of public health and forensic potential Peckia (Peckia) Chrysostoma. The ultrastructure of the antennae and male genitalia of Sarcophagidae species using SEM are limited in the literature, these sensorial and reproductive structure have been performed, such as: [19] described the ultrastructure of the adhesive device in Sarcophaga (Liosarcophaga) Dux showing the smooth surface and their implication as mechanical carriers of pathogens; [8] that described the male genitalia of S. (L.) Dux and observed sensilla on the surfaces of postgonite, surstylus, epandrium and cerci parts; [7] investigated the antenna and maxillary palp of Sarcophaga tibialis and described the sensillas in these sensorial structures. Different from what was seen above, the present study did not identify any of these structures. The 
external morphology of the antennae segments of $P$. (P.) Chrysostoma is generally similar to that of other Sarcophagidae and calyptrate flies $[7,13,19]$. In this study, the microtrichia morphology of the antennae is similar to that of other calyptrate and are present on all antennal surface with a variable distribution [7,11-13, 18,20,21].

The chaetic sensilla $(\mathrm{Ch})$ were observed in the scape Ch type I and pedicel segments (Ch types I and II). This distribution pattern was also found in Ophyra albuquerquei Lopes, Ophyra aenescens (Wiedemann) [13] and Ophyra chalcogaster [21], but differs of $S$. tibialis that have tree type of chaetic sensilla [7].

The flagellum is the largest segment of the antenna and its number of sensory sensilla can vary from species to species $[13,20]$. Two types of sensilla: trichoidea and two type of basiconic (Ba I and Ba II) were observed in the Fn of P. (Peckia) chrysostoma; those distribution differ of other dipteran species, such as O. chalcogaster [21], Musca domestica Linnaeus [20], Fannia scalaris and Fannia canicularis [12], Lispe neimongola Tian and Ma [11] P. terraenovae [18], O. albuquerquei and O. aenescens [13] Olfactory pits were observed in S. dux [20] and S. tibialis [7], but it was not observed in this study.

Some authors agree that male genitalia is the principal character to identify Sarcophagidae $[8,17,22,23]$, there is, however little information pertaining to the ultrastructure of their male genitalia [8]. In this study, terminal end of the J was slightly expanded with a laterally serrated structure, but it differs of those observed in $S$. (Liosarcophaga) dux that is apically bifurcated [23].

Taxonomical studies are important to the biological sciences in general, they are particularly relevant to entomology, because erroneous species identifications can mislead expert reports. The ultrastructure of the male genitalia will add morphological knowledge to identifying this species.

\section{Acknowledgement}

This research was carried out through the cooperation of Fundação Oswaldo Cruz (FIOCRUZ) and Instituto Samambaia de Ciências Ambientais e Ecoturismo (ISCAE), process number: 176/2016. We are grateful to Paulo Vander Ferreira Santana (a teacher from the Municipality of Rio de Janeiro) for his help with reviewing the English language part of the manuscript. We would like to thank the Platform Electron Microscopy Platform Rudolf Barth of Instituto Oswaldo Cruz (FIOCRUZ) for the use of the scanning electron microscope.

\section{References}

1. Barros RM, Mello-Patiu CA, Pujol-Luz JR. Sarcophagidae (Insecta, Diptera) associados à decomposição de carcaças de Sus scrofa Linnaeus (Suidae) em área de Cerrado do Distrito Federal, Brasil. Revista Brasileira de Entomologia. 2008; 52: 606-609.

2. Carriço C, Mendonça PM, Cortinhas LB, Mallet JR, Queiroz MM Ultrastructural studies of some character of Diptera (Muscidae) of forensically importance. Acta Trop. 2015; 142: 96-102.

3. Carvalho CJB, Mello-Patiu CA. Key to the adults of the most common forensic species of Diptera in South America. Revista Brasileira de Entomologia. 2008; 52: 390-406.

4. Chaiwong $\mathrm{T}$, Sukontason $\mathrm{KL}$, Chaithong $\mathrm{U}$, Olson JK, Kurahashi $\mathrm{H}$ Sukontason K. Male genitalia of flesh fly Parasarcophaga (Liosarcophaga) dux (Diptera: Sarcophagidae) revealed by scanning electron miscroscopy. J Am Mosq Control Assoc. 2007; 23: 80-83.
5. Catts EP, Goff ML. Forensic entomology in criminal investigations. Annu Rev Entomol. 1992; 37: 253-272.

6. Cumming JM, Wood MD. Adult morphology and terminology. In Brown B, Borkent A, Cumming J, Wood D, Woodley N, Zumbado M, editors. (Ed), Manual of Central American Diptera. Ottawa: NRC Research Press; 2009.

7. Cunha CL, Lomônaco C. Monitorização de impacto ambiental provocado por dispersão de moscas em bairros adjacentes a uma granja avícola. Anais da Sociedade Entomológica do Brasil. 1996; 25: 1-12.

8. Dahlem GA, Naczi RFC. Flesh flies (Diptera: Sarcophagidae) associated with North American pitcher plants (Sarraceniaceae, with descriptions of three new species. Annals of the Entomological Society America. 2006; 99: 218240 .

9. Greenberg B. Flies and Disease: I Ecology, Classification and Biotic Association. New Jersey: Princeton University Press; 1971. 447 pp.

10. Mc Alpine JF. Morphology and terminology - adults. In: Mc Alpine J.F., Peterson B.V., Shewell G.E., Teskey HJ, Vockeroth JR, Wood DM. (Eds) Manual of Neartic Diptera -1. Bio systematic Research Institute monograph. Otawa: Agriculture Canada; 1981; 27: 9-63.

11. Marchiori CH, Filho OMS. Peckia chrysostoma (Wiedemann) (Diptera: Sarcophagidae) e seus parasitóides coletados no sul do estado de Goiás. Revista Brasileira de Parasitologia Veterinária. 2004; 13: 165-168.

12. Oliveira-Costa J. Entomologia forense: quando os insetos são vestígios, 3rd (Ed). Millennium Editora, Campinas. 2011.

13. Pezzi M, Whitmore D, Chicca M, Semeraro B, Brighi F, Leis M. Ultrastructural morphology of the antenna and maxillary palp of Sarcophaga tibialis (Diptera: Sarcophagidae). J Med Entomol. 2016; 53: 807-814.

14. Setzu MD, Poddighe S, Angioy AM. Sensilla on the antennal funiculus of the blowfly. Protophormia terraenovae (Diptera: Calliphoridae). Micron. 2011; 42: 471-477.

15. Silva KP, Mello-Patiu CA. New species of Dexosarcophaga Townsend from Panama with an illustrated key to species of the subgenus Bezzisca (Diptera: Sarcophagidae). Journal of Natural History. 2010; 44: 89-106.

16. Sukontason K, Sukontason KL, Piangjaia S, Boonchua N, Chaiwonga T, Ngern-kluna R, et al. Antennal sensilla of some forensically importante flies in families Calliphoridae, Sacorphagidae and Muscidae. Micron. 2004; 35: 671-679.

17. Sukontason KL, Bunchu N, Methanitikorn R, Chaiwong T, Kuntalue B, Sukontason K. Ultrastructure of adhesive devise in fly in families Calliphoridae, Muscidae and Sarcophagidae, and their implication as mechanical carries of pathogens. Parasitol Res. 2006; 98: 477-481.

18. Sukontason K, Methanitikorn R, Chaiwong $T$, Kurahashi H, Vogtsberger RC, Sukontason KL. Sensilla of the antenna and palp of Hydrotaea chalcogaster (Diptera: Muscidae). Micron. 2007; 38: 218-223.

19. Sukontason KL, Sanit S, Klong-Klaew T, Tomberlin JK, Sukontason K. Sarcophaga (Liosarcophaga) dux (Diptera: Sarcophagidae): a flesh fly species of medial importance. Biological Research. 2014; 47: 1-9.

20. Vairo KP, Mello-Patiu CA, Carvalho CJB. Pictorial identification key for species of Sarcophagidae (Diptera) of potential forensic importance in southern Brazil. Revista Brasileira de Entomolologia. 2011; 55: 333-347.

21. Tullis K, Goff ML. Arthropod succession in exposed carrion in a tropical rainforest on O'ahu Island, Hawai'i. J Med Entomol. 1987; 24: 332-339.

22. D, Wang QK, Liu XH, Li K. Sensilla on antenna and maxillary palp of predaceous fly, Lispe neimongola Tian et Ma (Diptera: Muscidae). Micron. 2013; 49: 33-39.

23. Zhang D, Wang QK, Yang YZ, Chen YO, Li K. Sensory organs of the antenna of two Fannia species (Diptera: Fanniidae). Parasitol Res. 2013; 112: 2177 2185. 